\title{
Inhibition of VLA-4/VCAM-1-mediated Cell Adhesion by Triterpenoid Saponins from Bupleurum falcatum $\mathrm{L}$
}

\author{
Seung Woong Lee, ${ }^{\mathrm{a}}$ Min Seok Kim, ${ }^{\mathrm{a}, \dagger}$ Ju-Hwan Lim, Jong Sun Chang, Jin Ling, \\ Ki-Hwan Bae, ${ }^{\dagger}$ Woo Song Lee, ${ }^{*}$ and Mun-Chual Rho* \\ Eco-friendly Biomaterial Research Center, Korea Research Institute of Bioscience and Biotechnology, 1404 Sinjeong-dong, \\ Jeongeup-si, Jeonbuk 580-185, Korea.*E-mail: rho-m@kribb.re.kr (M.C.R.),wslee@kribb.re.kr (W.S.L) \\ †College of Pharmacy, Chungnam National University, Daejeon 305-764, Korea \\ Received January 27, 2010, Accepted May 3, 2010
}

\begin{abstract}
Discovery and isolation of compounds capable of blocking the interactions between VCAM-1 and VLA-4, a major pair of adhesion molecules contributing to the different steps of leukocyte migration across the endothelium in inflammatory responses, has been a major goal of this lab. Through bioactivity-guided fractionation, five saikosaponins were subsequently isolated from the methanol extracts of the roots of Bupleurum falcatum L. Their structures were elucidated by spectroscopic analysis ( ${ }^{1} \mathrm{H}-,{ }^{13} \mathrm{C}-\mathrm{NMR}$ and 2D-NMR), as follows, saikosaponins: A (1); D (2); C (3); B3 (4); B4 (5). Compounds 1 and 2 inhibited interaction of sVCAM- 1 and VLA- 4 of THP-1 cells with respective $\mathrm{IC}_{50}$ values of 7.8 and $1.7 \mu \mathrm{M}$. The aglycone structure of $\mathbf{2}$ also showed cell adhesion inhibitory activity with an $\mathrm{IC}_{50}$ value of $21.1 \mu \mathrm{M}$. With these results, we suspect these two saikosaponins from the Bupleurum falcatum L. roots to be prime candidates for therapeutic strategies towards inflammation.
\end{abstract}

Key Words: Bupleurum falcatum L, Umbelliferae, Vascular cell adhesion molecule-1 (VCAM-1), Very late antigen-4 (VLA-4), Saikosaponins

\section{Introduction}

Leukocytes and monocytes adhere and firmly bind to the vascular endothelium through interaction of integrins (LFA-1, leukocyte function-associated antigen-1; VLA-4, very late antigen4) and cell adhesion molecules (CAMs) such as intercellular cell adhesion molecule-1 (ICAM-1) and vascular cell adhesion molecule-1 (VCAM-1), during the inflammation processes. ${ }^{1-3}$ Integrins and CAMs also take part in leukocyte spreading and migration across the vascular endothelium into tissue. ${ }^{4}$ In particular, VLA-4 ( $\alpha 4 \beta 1$ integrin, CD49d/CD29) has been reported in various types of inflammatory cells, including eosinophils and T cells, ${ }^{5}$ with the interaction between VLA-4 and its ligand VCAM-1 considered necessary in the inflammatory processes. ${ }^{6}$ Therefore, several strategies have been developed to block the interaction of VLA-4 and VCAM for inflammation and autoimmune diseases. Anti- $\alpha 4$ monoclonal antibodies and small molecular antagonists ${ }^{7}$ for VLA-4 possess reported efficacies in many animal models of inflammatory disease, including asthma, ${ }^{8}$ multiple sclerosis, ${ }^{9}$ rheumatoid arthritis, ${ }^{10}$ and inflammatory bowel disease (IBD). ${ }^{11}$ A humanized anti-VLA-4 antibody such as natalizumab has been approved in the treatment of multiple sclerosis (MS) and Crohn's disease. ${ }^{12,13}$

In our search for cell adhesion inhibitors from natural sources, the methanol extracts of Bupleurum falcatum L. showed inhibitory activity in the VCAM-1/VLA-4-mediated cell adhesion assay. Bupleurum falcatum L. belongs to the family of Umbelliferae and is one of the most widely used components in traditional oriental medicines for the treatment of chronic hepatitis and auto-immune disease. ${ }^{14}$ Bupleurum falcatum, or its important principle saikosaponins, is known to have numerous phar-

${ }^{\mathrm{a}}$ Both authors equally contributed to this work. macological activities, including anti-inflammatory, ${ }^{15,16}$ antipyretic, ${ }^{17}$ and antitussive actions. ${ }^{14}$

Accordingly, we herein report the isolation and structural elucidation of compounds 1-5 from Bupleurum falcatum and their inhibition of VLA-4/VCAM-1 interaction.

\section{Experimental Section}

General experimental procedures. ${ }^{1} \mathrm{H}-\mathrm{NMR}$ (300 and 500 $\mathrm{MHz}$ ), ${ }^{13} \mathrm{C}-\mathrm{NMR}$ (75 and $125 \mathrm{MHz}$ ), HMQC, and HMBC spectra were obtained on a Varian Unity 300 and Bruker Biospin Avance 500 spectrometer, with pyridine- $d_{5}$ as the solvent. The ESI-MS was determined using a Finnigan ${ }^{\mathrm{TM}}$ navigator spectrometer. The HPLC system consisted of a Hitachi Model L-2130 pump, L-2400 UV detector and YMC J'sphere ODS H-80 column (4 $\mu \mathrm{m}, \phi 20 \times 150 \mathrm{~mm}$, YMC Co. LTD.). Reversed-phase CC was conducted using RP-C18 silica gel (Cosmosil 140 C18-PREP, $140 \mu \mathrm{m}$, Nacalai tesque, INC.). Silica gel CC was conducted using Kieselgel 60 (70 - 230 and 230 - 400 mesh, Merck). TLC was conducted using Kieselgel 60 F254 plates (Merck).

Extraction and isolation. The Bupleurum falcatum roots were purchased at an herbal market in Daejeon, Korea. A voucher specimen (PBC-247A) was deposited in the Korea Plant Extract Bank, at the Korea Research Institute of Bioscience and Biotechnology. The dried roots of the Bupleurum falcatum $(2.4 \mathrm{~kg})$ were extracted with methanol $(10.0 \mathrm{~L})$ for $7 \mathrm{~d}$ at room temperature. The methanol extract was evaporated in vacuo, yielding a residue $(435.0 \mathrm{~g})$. The residue was suspended in distilled water $(2.0 \mathrm{~L})$ and extracted with $\mathrm{CHCl}_{3}(8.0 \mathrm{~L})$. The $\mathrm{CHCl}_{3}$ layers were then evaporated in vacuo, with the resulting extract (180.0 g) subjected to silica gel (230 - 400 mesh, $1.8 \mathrm{~kg}$, Merck) 
column chromatography using a gradient of $\mathrm{CHCl}_{3}-\mathrm{MeOH}$ (100:0, 90:1, 70:1, 50:1, 30:1, 15:1, 5:1, 1:1; each 3.0 L, v/v). Based on the TLC profile, 19 fractions (F1 19) were collected, with each fraction monitored by the in vitro cell adhesion inhibitory assay. Fraction F18 (15.0 g) showed the highest inhibitory effect and was subjected to reverse-phase column chromatography $(300.0 \mathrm{~g})$, eluted with $\mathrm{MeOH}-\mathrm{H}_{2} \mathrm{O}(70: 30,80: 20,90: 10$, 100:0; each $2.0 \mathrm{~L}, \mathrm{v} / \mathrm{v})$, to yield 11 sub-fractions (F18-1 11), based on the TLC profile. Fraction F18-4 (686.7 mg) was successively separated by semi-preparative HPLC (YMC-pack ODS-H80, $4 \mu \mathrm{m}, 250 \times 20 \mathrm{~mm}$, flow rate $5.0 \mathrm{~mL} / \mathrm{min})$, eluting with $\mathrm{MeOH}-\mathrm{H}_{2} \mathrm{O}(75: 25, \mathrm{v} / \mathrm{v})$, to yield $1\left(130.2 \mathrm{mg}, t_{\mathrm{R}} 65 \mathrm{~min}\right)$ and a mixture peak $\left(70.0 \mathrm{mg}, t_{\mathrm{R}} 27 \mathrm{~min}\right)$. The mixture peak was successively separated by semi-preparative HPLC (MeOH$\left.\mathrm{H}_{2} \mathrm{O}, 65: 35, \mathrm{v} / \mathrm{v}\right)$, yielding 2 (18.0 $\left.\mathrm{mg}, t_{\mathrm{R}} 55 \mathrm{~min}\right)$. In addition, F18-3 (680.4 mg) was successively separated by semipreparative HPLC (MeOH-H ${ }_{2} \mathrm{O}, 65: 35$, v/v), yielding $3\left(66.8 \mathrm{mg}, t_{\mathrm{R}} 17\right.$ $\mathrm{min}), 4$ (19.6 mg, $\left.t_{\mathrm{R}} 24 \mathrm{~min}\right)$, and 5 (18.1 mg, $\left.t_{\mathrm{R}} 49 \mathrm{~min}\right)$.

Saikosaponin A (1): ${ }^{18-21}$ White amorphous powder. $\mathrm{C}_{42} \mathrm{H}_{68}-$ $\mathrm{O}_{13}$. ESI-MS $m / z$ 804.0 [M+Na $]^{+}, m / z 780.0[\mathrm{M}-\mathrm{H}]^{+}$. ${ }^{1} \mathrm{H}-\mathrm{NMR}$ $\left(500 \mathrm{MHz}\right.$, pyridine- $\left.d_{5}\right) \delta 6.01(1 \mathrm{H}, \mathrm{d}, J=10.0 \mathrm{~Hz}, \mathrm{H}-12), 5.67$ $(1 \mathrm{H}, \mathrm{dd}, J=2.8,10.3 \mathrm{~Hz}, \mathrm{H}-11), 4.38(1 \mathrm{H}, \mathrm{m}, \mathrm{H}-16), 1.44(3 \mathrm{H}$, d, $J=6.5 \mathrm{~Hz}, \mathrm{H}-6$ '), 1.41 (3H, s, H-26), 1.11 (3H, s, H-27), 1.00 (3H, s, H-25), 0.94 (3H, s, H-29), 0.93 (3H, s, H-24), 0.90 (3H, s, H-30). ${ }^{13} \mathrm{C}-\mathrm{NMR}\left(125 \mathrm{MHz}\right.$, pyridine- $\left.d_{5}\right) \delta 13.4$ (C-24), 17.6 (C-6'), 17.9 (C-6), 19.1 (C-25), 20.4 (C-26), 21.2 (C-27), 24.2 (C-30), 26.1 (C-22), 26.5 (C-2), 31.9 (C-20), 32.0 (C-7), 34.0 (C-29), 35.0 (C-21), 36.5 (C-15), 36.6 (C-10), 38.1 (C-19), 39.0 (C-1), 42.6 (C-8), 44.1 (C-4), 46.0 (C-14), 47.3 (C-17), 47.7 (C-5), 52.5 (C-18), 53.5 (C-9), 63.1 (C-6"), 64.3 (C-16), 64.4 (C-23), 71.4 (C-5'), 72.0 (C-2'), 72.2 (C-4'), 72.5 (C-4"), 73.4 (C-28), 76.2 (C-2"), 78.8 (C-5"), 79.2 (C-3"), 81.9 (C-3), 84.3 (C-13), 85.6(C-3'), 106.4 (C-1'), 107.1 (C-1"), 131.5 (C-11), 132.5 (C-12).

Saikosaponin D (2): ${ }^{18-21}$ White amorphous powder. $\mathrm{C}_{42} \mathrm{H}_{68}-$ $\mathrm{O}_{13}$. ESI-MS $m / z$ 804.0 $[\mathrm{M}+\mathrm{Na}]^{+}, m / z 780.0[\mathrm{M}-\mathrm{H}]^{+}$. ${ }^{1} \mathrm{H}-\mathrm{NMR}$ $\left(500 \mathrm{MHz}\right.$, pyridine- $\left.d_{5}\right) \delta 6.05(1 \mathrm{H}, \mathrm{d}, J=10.5 \mathrm{~Hz}, \mathrm{H}-12), 5.71$ $(1 \mathrm{H}, \mathrm{dd}, J=3.0,10.0 \mathrm{~Hz}, \mathrm{H}-11), 4.23$ (1H, m, H-16), $1.64(3 \mathrm{H}$, s, H-25), 1.45 (3H, d, J=6.5 Hz, H-6'), 1.37 (3H, s, H-27), 1.04 (3H, s, H-26), 1.04 (3H, s, H-29), 0.97 (3H, s, H-30), 0.95 (3H, s, H-24). ${ }^{13} \mathrm{C}-\mathrm{NMR}\left(125 \mathrm{MHz}\right.$, pyridine- $\left.d_{5}\right) \delta 13.5$ (C-24), 17.6 (C-6'), 18.0 (C-6), 18.5 (C-25), 19.2 (C-26), 19.9 (C-27), 24.8 (C-30), 26.5 (C-2), 31.7 (C-22), 31.9 (C-20), 32.3 (C-7), 34.1 (C-29), 35.9 (C-21), 36.7 (C-15), 37.2 (C-10), 38.8 (C-19), 39.0 (C-1), 42.3 (C-8), 44.0 (C-4), 44.1 (C-14), 45.7 (C-17), 47.8 (C-5), 51.7 (C-18), 53.4 (C-9), 63.1 (C-6"), 64.4 (C-23), 71.4 (C-5'), 72.0 (C-2'), 72.2 (C-4'), 72.6 (C-4"), 76.2 (C-2"), 77.5 (C-16), 78.2 (C-28), 78.9 (C-5"), 79.2 (C-3"), 82.0 (C-3), 85.3 (C-13), 85.6 (C-3'), 106.4 (C-1'), 107.2 (C-1"), 132.4 (C-12), 132.4 (C-11).

Saikosaponin C (3): ${ }^{18-21}$ White amorphous powder. $\mathrm{C}_{48} \mathrm{H}_{78}-$ $\mathrm{O}_{17}$. ESI-MS $m / z$ 950.2 [M+Na] $]^{+}, m / z 926.2[\mathrm{M}-\mathrm{H}]^{+}$. ${ }^{1} \mathrm{H}-\mathrm{NMR}$ (300 MHz, pyridine- $\left.d_{5}\right) \delta 5.99(1 \mathrm{H}, \mathrm{d}, J=10.1 \mathrm{~Hz}, \mathrm{H}-11), 5.64$ $(1 \mathrm{H}, \mathrm{d}, J=10.1 \mathrm{~Hz}, \mathrm{H}-12), 4.32$ (1H, m, H-16), 1.69 (3H, d, $J=$ $6.1 \mathrm{~Hz}, \mathrm{H}-6 "), 1.37$ (3H, s, H-26), 1.31 (3H, s, H-23), 1.16 (3H, s, H-27), 0.99 (3H, s, H- 29), 0.98 (3H, s, H-25), 0.94 (3H, s, $\mathrm{H}-30), 0.88(3 \mathrm{H}, \mathrm{s}, \mathrm{H}-24) .{ }^{13} \mathrm{C}-\mathrm{NMR}\left(75 \mathrm{MHz}\right.$, pyridine- $\left.d_{5}\right) \delta$ 16.8 (C-24), 18.3 (C-6"), 18.6 (C-25), 18.9 (C-6), 20.4 (C-26),
21.3 (C-27), 24.3 (C-30), 26.2 (C-22), 26.9 (C-2), 28.3 (C-23), 32.1 (C-20), 32.3 (C-7), 34.1 (C-29), 35.1 (C-21), 36.6 (C-15), 36.7 (C-10), 38.2 (C-19), 38.9 (C-1), 40.1 (C-4), 42.6 (C-8), 46.1 (C-14), 47.4 (C-17), 52.6 (C-18), 53.3 (C-9), 55.7 (C-5), 63.0 (C-6"'), 64.5 (C- 16), 69.5 (C-6'), 71.0 (C-5"), 71.8 (C-4"'), 73.0 (C-2"), 73.1 (C- 3'), 73.5 (C-28), 74.3 (C-4"), 75.2 (C-2"'), 75.6 (C-2'), 76.0 (C- 5'), 77.2 (C-3'), 78.8 (C-3"'), 78.9 (C-5"'), 80.3 (C-4'), 84.4 (C-13), 89.5 (C-3), 103.4 (C-1'), 105.6 (C-1"'), 107.2 (C-1'), 131.6 (C-12), 132.5 (C-11).

Saikosaponin B3 (4): ${ }^{18-21}$ White amorphous powder. $\mathrm{C}_{43} \mathrm{H}_{72^{-}}$ $\mathrm{O}_{14}$. ESI-MS $m / z$ 836.1 [M+Na] $]^{+}, m / z 812.2[\mathrm{M}-\mathrm{H}]^{+}$. ${ }^{1} \mathrm{H}-\mathrm{NMR}$ $\left(300 \mathrm{MHz}\right.$, pyridine- $\left.d_{5}\right) \delta 4.33(1 \mathrm{H}, \mathrm{m}, \mathrm{H}-16), 3.25(3 \mathrm{H}, \mathrm{s}$, $\left.-\mathrm{OCH}_{3}\right), 1.44(3 \mathrm{H}, \mathrm{s}, \mathrm{H}-6$ '), 1.42 (3H, s, H-26), 1.14 (3H, s, H27), 1.10 (3H, s, H-25), 1.02 (3H, s, H-29), 0.98 (3H, s, H-30), $0.91(3 \mathrm{H}, \mathrm{s}, \mathrm{H}-24) .{ }^{13} \mathrm{C}-\mathrm{NMR}\left(75 \mathrm{MHz}\right.$, pyridine- $\left.d_{5}\right) \delta 14.1(\mathrm{C}-$ 24), 17.0 (C-6'), 18.4 (C-25), 18.7 (C-26), 18.8 (C-6), 24.4 (C30), 26.4 (C-22), 26.7 (C-27), 26.9 (C-2), 31.5 (C-20), 33.6 (C-29), 33.7 (C-7), 34.6 (C-21), 37.3 (C-15), 38.5 (C-10), 40.6 (C-1), 41.4 (C-8), 44.1 (C-4), 44.3 (C-17), 44.3 (C-18), 44.4 (C-14), 47.4 (C-19), 48.1 (C-5), 52.5 (C-9), 54.4 (C-OMe), 63.2 (C-6"), 64.7 (C-23), 66.6 (C-16), 69.0 (C-28), 71.5 (C-5'), 72.0 (C-2'), 72.3 (C-4'), 72.6 (C-4"), 76.3 (C-2"), 76.4 (C-11), 78.9 (C-3"), 79.2 (C-5"), 82.2 (C-3), 85.8 (C-3'), 106.5 (C-1'), 107.2 (C-1"), 123.0 (C-12), 148.7 (C-13).

Saikosaponin B4 (5): ${ }^{18-21}$ White amorphous powder. $\mathrm{C}_{43} \mathrm{H}_{72-}$ $\mathrm{O}_{14}$. ESI-MS $m / z$ 836.1 [M+Na] ${ }^{+}, m / z$ 812.2 [M-H] ${ }^{+}$. ${ }^{1} \mathrm{H}-\mathrm{NMR}$ (300 MHz, pyridine- $\left.d_{5}\right) \delta 4.26(1 \mathrm{H}, \mathrm{m}, \mathrm{H}-16), 3.29(3 \mathrm{H}, \mathrm{s}$, $\left.-\mathrm{OCH}_{3}\right), 1.44$ (3H, s, H-6'), 1.42 (3H, s, H-26), 1.17 (3H, s, H27), 1.15 (3H, s, H-25), 1.03 (3H, s, H-30), 1.03 (3H, s, H-29), $0.99(3 \mathrm{H}, \mathrm{s}, \mathrm{H}-24) .{ }^{13} \mathrm{C}-\mathrm{NMR}\left(75 \mathrm{MHz}\right.$, pyridine- $\left.d_{5}\right) \delta 14.1(\mathrm{C}-$ 24), 17.7 (C-6'), 18.4 (C-25), 18.5 (C-26), 18.9 (C-6), 25.1 (C30), 26.9 (C-27), 27.0 (C-2), 31.4 (C-22), 31.8 (C-20), 33.9 (C-29), 35.5 (C-7), 37.7 (C-21), 38.7 (C-15), 40.6 (C-10), 41.2 (C-1), 42.4 (C-8), 42.4 (C-4), 43.9 (C-17), 44.3 (C-18), 48.2 (C-14), 48.9 (C-19), 50.1 (C-5), 52.2 (C-9), 54.3 (C-OMe), 63.2 (C-6"), 64.8 (C-23), 70.5 (C-28), 71.5 (C-5'), 72.0 (C-2'), 72.3 (C-4'), 72.7 (C-4"), 74.6 (C-16), 76.3 (C-2"), 76.5 (C-11), 78.9 (C-3"), 79.3 (C-5"), 82.3 (C-3), 85.8 (C-3'), 106.5 (C-1'), 107.2 (C-1"), 122.9 (C-12), 150.7 (C-13).

Alcoholic alkali metal treatment of compound 2. ${ }^{22} \mathrm{Com}-$ pound $2(70.0 \mathrm{mg})$ was dissolved in butanol $(10.5 \mathrm{~mL})$, followed by addition of sodium metal $(350.0 \mathrm{mg})$. This mixture was allowed to react for $6 \mathrm{hr}$ at $80{ }^{\circ} \mathrm{C}$. Water was then added to stop the reaction. The butanol layer was washed with water three times and evaporated to dryness. The residue was then separated by semi-preparative HPLC $\left(\mathrm{MeOH}-\mathrm{H}_{2} \mathrm{O}, 75: 25\right.$, v/v), yielding 6 $\left(15.0 \mathrm{mg}, t_{\mathrm{R}} 16 \mathrm{~min}\right)$.

Saikogenin G (6): ${ }^{23-25}$ White amorphous powder. $\mathrm{C}_{30} \mathrm{H}_{48} \mathrm{O}_{4}$. ESI-MS $m / z 471.8[\mathrm{M}-\mathrm{H}]^{+} .{ }^{1} \mathrm{H}-\mathrm{NMR}$ (500 MHz, pyridine- $d_{5}$ ) $\delta 6.08(1 \mathrm{H}, \mathrm{d}, J=10.0 \mathrm{~Hz}, \mathrm{H}-12), 5.73(1 \mathrm{H}, \mathrm{dd}, J=3.0,10.0 \mathrm{~Hz}$, H-11), 4.25 (1H, m, H-16), 1.63 (3H, s, H-25), 1.40 (3H, s, H27), 1.09 (3H, s, H-24), 1.09 (3H, s, H-26), 1.04 (3H, s, H-29), $0.98(3 \mathrm{H}, \mathrm{s}, \mathrm{H}-30) .{ }^{13} \mathrm{C}-\mathrm{NMR}\left(125 \mathrm{MHz}\right.$, pyridine- $\left.d_{5}\right) \delta 13.0$ (C-24), 18.4 (C-6), 18.5 (C-25), 19.1 (C-26), 20.0 (C-27), 24.8 (C-30), 28.0 (C-2), 31.7 (C-22), 32.0 (C-20), 32.3 (C-7), 34.2 (C-29), 35.8 (C-21), 37.0 (C-15), 37.2 (C-10), 38.8 (C-19), 39.1 (C-1), 42.3 (C-8), 43.5 (C-4), 44.0 (C-14), 45.8 (C-17), 48.8 (C-5), 51.8 (C-18), 53.4 (C-9), 68.0 (C-23), 73.6 (C-16), 
77.5 (C-28), 78.2 (C-3), 85.3 (C-13), 132.4 (C-11), 132.5 (C-12).

HPLC-ESI-MS analysis. For LC-ESI-MS analysis, an Agilent 1100 HPLC system coupled with an esquire 6000 mass spectrometer (Bruker daltonics, USA was used. Chromatography was performed on a ZORBAX SB-Aq C18 column ( $5 \mu \mathrm{m}$, $4.6 \times 150 \mathrm{~mm}$ id, Agilent, USA) at a column temperature of 30 ${ }^{\circ} \mathrm{C}$ and flow rate of $0.5 \mathrm{~mL} / \mathrm{min}$, using $\mathrm{MeOH}-\mathrm{H}_{2} \mathrm{O}(8: 2, \mathrm{v} / \mathrm{v})$ as the mobile phase on an Agilent 1100 HPLC system. The acquisition parameters were as follows: nebulizer gas, $\mathrm{N}_{2}$; nebulizer gas pressure, $70 \mathrm{psi}$; dry gas, $5.0 \mathrm{~L} / \mathrm{min}$; dry temperature, $300{ }^{\circ} \mathrm{C}$; HV capillary, $2500 \mathrm{~V}$; compound stability, 100\%; Trap drive level, $100 \%$.

Adhesion of THP-1 on immobilized sVCAM-1. Human acute monocytic leukemia THP-1 cells were obtained from the American Type Culture Collection (ATCC, Manassas, VA, USA). The cells were grown in RPMI-1640 medium supplemented with $10 \%$ fetal bovine serum (FBS) and incubated at $37{ }^{\circ} \mathrm{C}$ and $5 \% \mathrm{CO}_{2}$ in a humidified atmosphere. An adhesion assay using soluble VCAM-1 and THP-1 cells was performed as described ${ }^{26}$ with slight modifications. Ninety six-well plates were coated with $100.0 \mu \mathrm{L}$ of recombinant VCAM-1 (R\&D systems) for $3 \sim 4 \mathrm{hr}$ at $37^{\circ} \mathrm{C}$ at a concentration of $1.5 \mu \mathrm{g} / \mathrm{mL}$ in PBS. The wells were then washed twice with PBS and blocked by addition of $200.0 \mu \mathrm{L}$ of PBS with $1 \%$ BSA by incubation for $1 \mathrm{hr}$ at room temperature. For fluorescent labeling of THP-1 cells, $1.0 \times 10^{6}$ cells washed once in RPMI 1640 were resuspended in $12.0 \mathrm{~mL}$ of RPMI 1640 containing $2.0 \mu \mathrm{M}$ BCECFAM, incubated at $37{ }^{\circ} \mathrm{C}$ for $1 \mathrm{hr}$, and washed once with RPMI $1640 / 0.1 \%$ fetal bovine serum. Then, fluorescent-labeled THP-1 cells and 5.0 $\mu \mathrm{L}$ of the compounds were added to each well. The plates were incubated for $1 \mathrm{hr}$ at $37^{\circ} \mathrm{C}$ and the wells washed gently once with RPMI 1640/0.1\% fetal bovine serum. Fluorescent intensity was measured with a fluorescent plate reader at an excitation wavelength of $485 \mathrm{~nm}$ and an emission wavelength of $530 \mathrm{~nm}$.

Cell viability assay. Cell viability was assessed by morphology and by reduction of the tetrazolium salt (MTT) as previously described. ${ }^{27}$ The absorbance was read at $540 \mathrm{~nm}$ using a microplate reader (Bio-rad, USA), with a reference absorbance at $650 \mathrm{~nm}$.

Data analysis. Each experiment was performed at least in duplicate. Results were expressed or plotted as the mean value \pm standard error (SE).

\section{Results and Discussion}

During an investigation of cell adhesion inhibitors from natural sources, the methanol extracts of the roots of Bupleurum falcatum were observed to inhibit interaction of VCAM- 1 and VLA-4 of THP-1 cells by $90 \%$ at $30.0 \mu \mathrm{g} / \mathrm{mL}$. The extract was partitioned with $\mathrm{CHCl}_{3}$, with the $\mathrm{CHCl}_{3}$-soluble material showing $98 \%$ inhibitory activity at $10.0 \mu \mathrm{g} / \mathrm{mL}$ (Figure 1 ). Therefore, the $\mathrm{CHCl}_{3}$-soluble material was fractionated via open-column chromatography on silica gel and ODS and subjected to semipreparative HPLC to yield compounds 1-5. Compound $\mathbf{1}$ was suggested to have two sugar moieties upon observation of two anomeric proton signals at $\delta 5.35(1 \mathrm{H}, \mathrm{d}, J=8.0 \mathrm{~Hz}, \mathrm{H}-1 ")$ and $4.99\left(1 \mathrm{H}, \mathrm{d}, J=8.0 \mathrm{~Hz}, \mathrm{H}-1^{\prime}\right)$ in the ${ }^{1} \mathrm{H}-\mathrm{NMR}$ spectrum, and

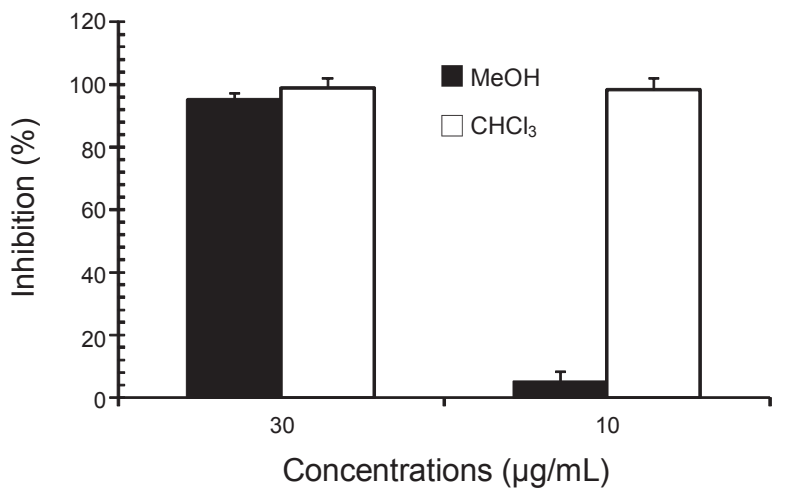

Figure 1. Effect of solvent extracts on the binding between SVCAM-1 and VLA- 4 of THP-1 cells. BCECF-AM-labeled THP-1 cells and solvent extracts (MeOH and EtOAc) of Bupleurum falcatum L. were added to 96-well plates and coated with SVCAM-1. After incubation for 1 hr at $37{ }^{\circ} \mathrm{C}$, the activity was measured as described in Materials and Methods. The data are presented as the means of three independent experiments performed in duplicate.

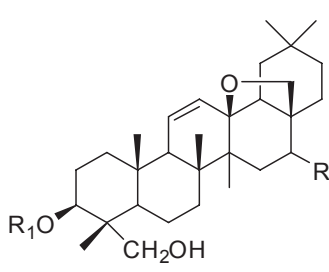

$\mathrm{R}_{1} \quad \mathrm{R}_{2}$

1. Saikosaponin A Glc-Fuc- $\quad \beta-O H$

2. Saikosaponin D Glc-Fuc- $\alpha-\mathrm{OH}$

3. Saikosaponin C Glc-Glc- $\beta-\mathrm{OH}$ Rham

6. Saikogenin G H $\quad \alpha-O H$

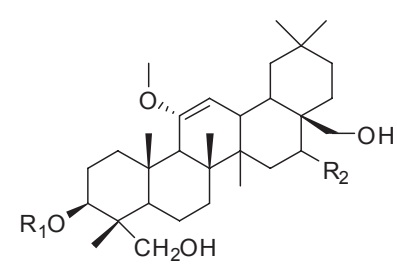

$\mathrm{R}_{1} \quad \mathrm{R}_{2}$ 4. Saikosaponin B3 Glc-Fuc- $\beta-\mathrm{OH}$ 5. Saikosaponin B4 Glc-Fuc- $\alpha-\mathrm{OH}$

Figure 2. Structures of saikosaponins (1-5) and saikogenin G (6)

two anomeric carbon signals at $\delta 107.1\left(\mathrm{C}-1^{\prime \prime}\right)$ and 106.4 (C-1') in the ${ }^{13} \mathrm{C}-\mathrm{NMR}$ spectrum. Similarly, 2, 4, and $\mathbf{5}$ showed two anomeric proton and carbon signals in the NMR spectra, but $\mathbf{3}$ had three sugar moieties, upon observation of three anomeric carbon signals $\delta 107.2$ (C-1"), 105.6 (C-1'") and 1,03.4 (C-1') in the ${ }^{13} \mathrm{C}$-NMR spectrum. Compound 1 had two olefinic proton signals at $\delta 6.01(1 \mathrm{H}, \mathrm{d}, J=10.0 \mathrm{~Hz}, \mathrm{H}-12)$ and $5.67(1 \mathrm{H}, \mathrm{dd}$, $J=2.8,10.3 \mathrm{~Hz}, \mathrm{H}-11)$, and seven methyl protons at $\delta 1.44,1.41$, $1.11,1.00,0.94,0.93$, and 0.90 (each $3 \mathrm{H}, \mathrm{s}, \mathrm{H}-24,25,26,27,29$, 30,6 '-Me) were also detected in the ${ }^{1} \mathrm{H}-\mathrm{NMR}$ spectrum. Compound $\mathbf{2}$ also had two olefinic and seven methyl proton signals, while 3 had an olefinic and eight methyl proton signals in the ${ }^{1} \mathrm{H}-\mathrm{NMR}$ spectrum. Additionally, the ${ }^{1} \mathrm{H}-\mathrm{NMR}$ spectrum exhibited signals due to methoxy protons at $\delta 3.25\left(3 \mathrm{H}, \mathrm{s},-\mathrm{OCH}_{3}\right)$ and $3.29\left(3 \mathrm{H}, \mathrm{s},-\mathrm{OCH}_{3}\right)$ from 4 and $\mathbf{5}$, respectively. As shown in Figure 2, their structures were confirmed through NMR and MS spectra analyses, and compared with literature published data, ${ }^{18-21}$ as saikosaponins A (1), D (2), C (3), B3 (4), and B4 (5).

The effects of 1-5 on the binding between VLA-4 of THP-1 cells and recombinant sVCAM-1 (R\&D systems), using a modified ELISA method, were then tested. ${ }^{26}$ Compounds $\mathbf{1}$ and $\mathbf{2}$ 
(a)

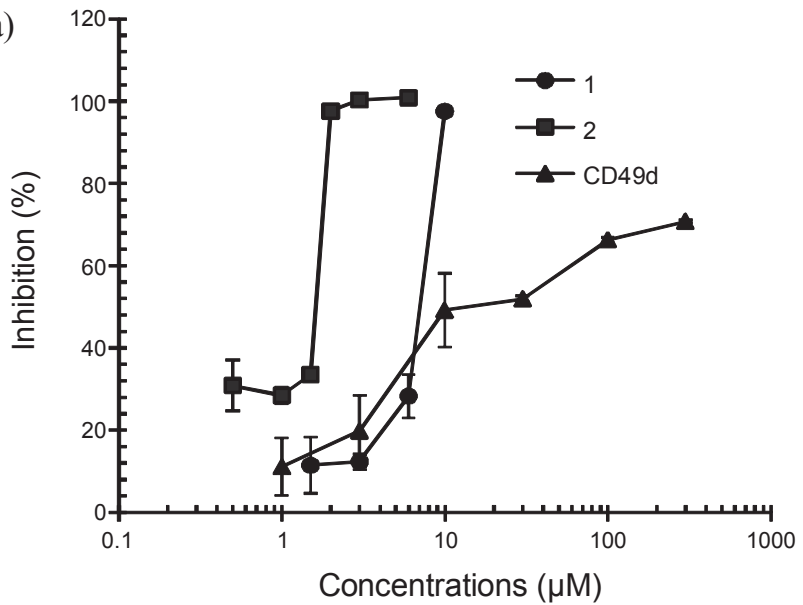

(b)
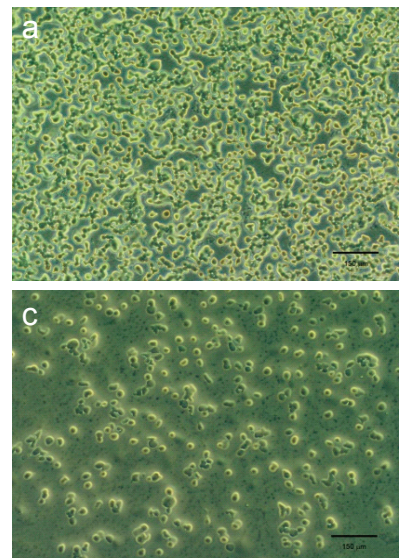

b

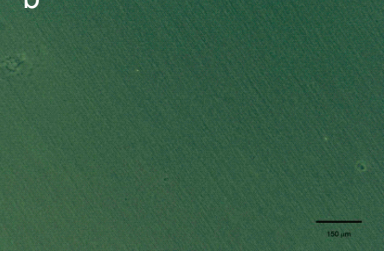

d

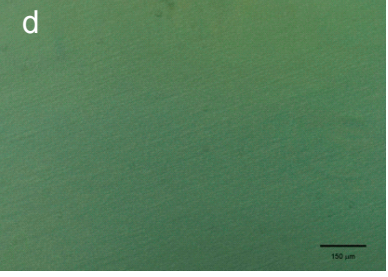

Scale Bar $=150 \mu \mathrm{m}$

Figure 3. Inhibitory effects of $\mathbf{1}$ and $\mathbf{2}$ on the binding between sVCAM- 1 and VLA- 4 of THP- 1 cells. (a) BCECF-AM-labeled THP-1 cells and test compounds (1 and 2) were added to 96-well plates coated with sVCAM-1. After incubation for $1 \mathrm{hr}$ at $37^{\circ} \mathrm{C}$, cells were dissolved in $1 \%$ Triton X-100 in PBS, and fluorescent intensity measured as described in Material and Methods. Monoclonal antibody (CD49d) was used as a positive control. The data are presented as the means of three independent experiments performed in duplicate. (b) The attachment of THP-1 cells was observed by microscopy (Nikon eclipse TS100). Total magnification was $\times 100$. a: cells added to wells coated with sVCAM-1; b: cells added to wells not coated with sVCAM1 ; c: cells and $\mathbf{1}(10.0 \mu \mathrm{M})$ added to wells coated with sVCAM-1; d: cells and $\mathbf{2}(3.0 \mu \mathrm{M})$ added to wells coated with sVCAM-1.

(a)

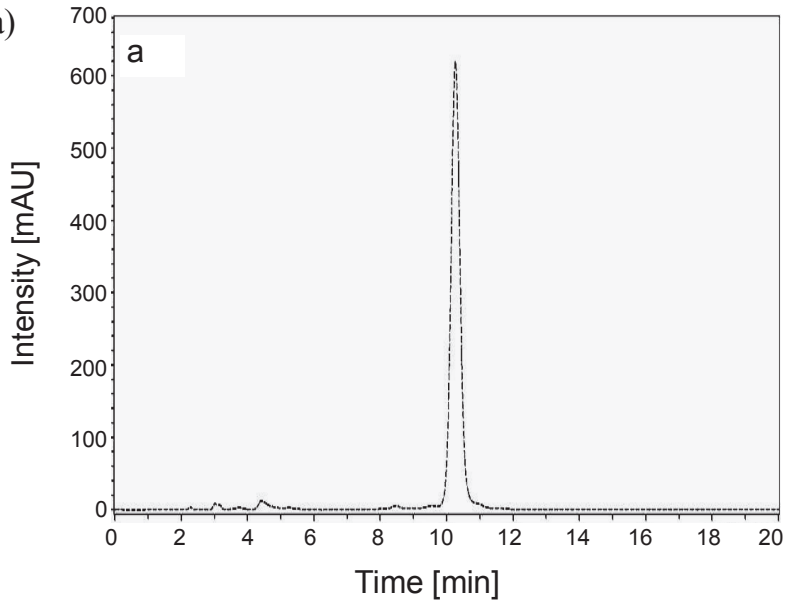

(b)

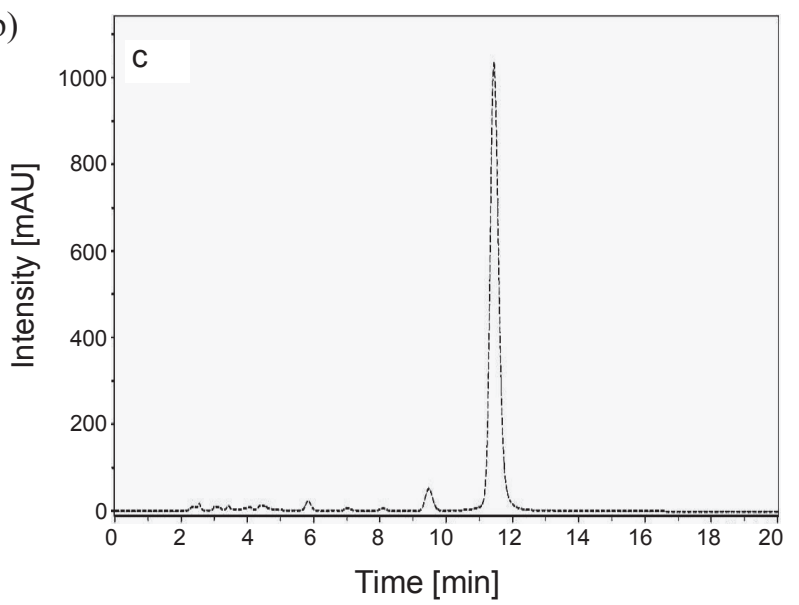

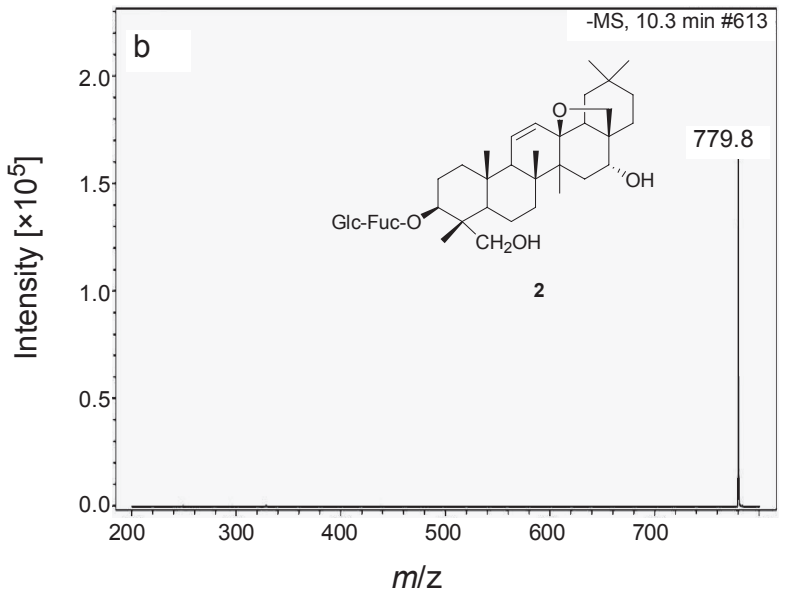

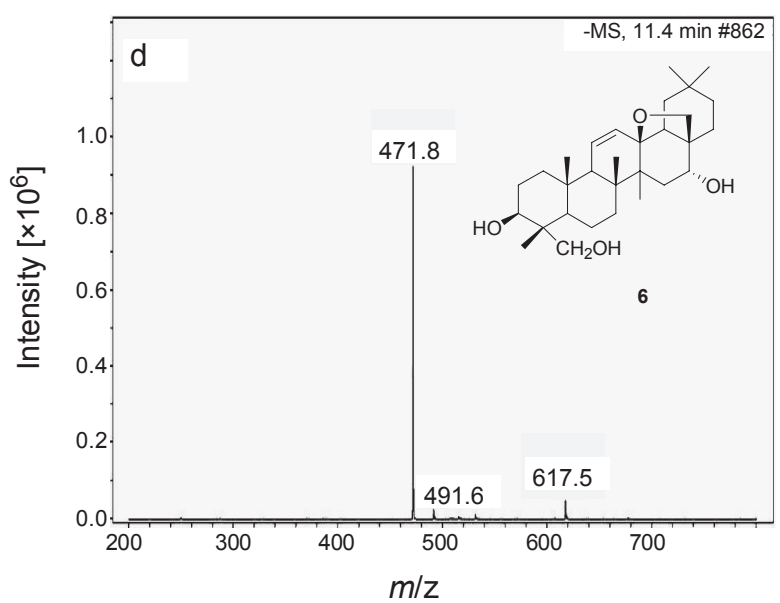

Figure 4. HPLC chromatograms and negative ESI-MS spectra of 2 (a) and 6 (b). (a)-a: HPLC chromatogram of 2; (a)-b: MS spectra of 2; (b)-a: HPLC chromatogram of 6 ; (b)-b: MS spectra of 6 . 
(a)

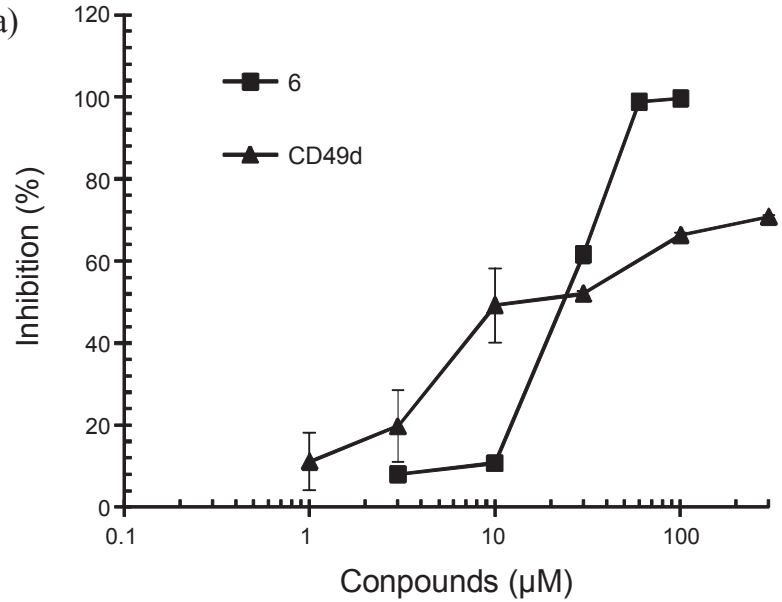

(b)
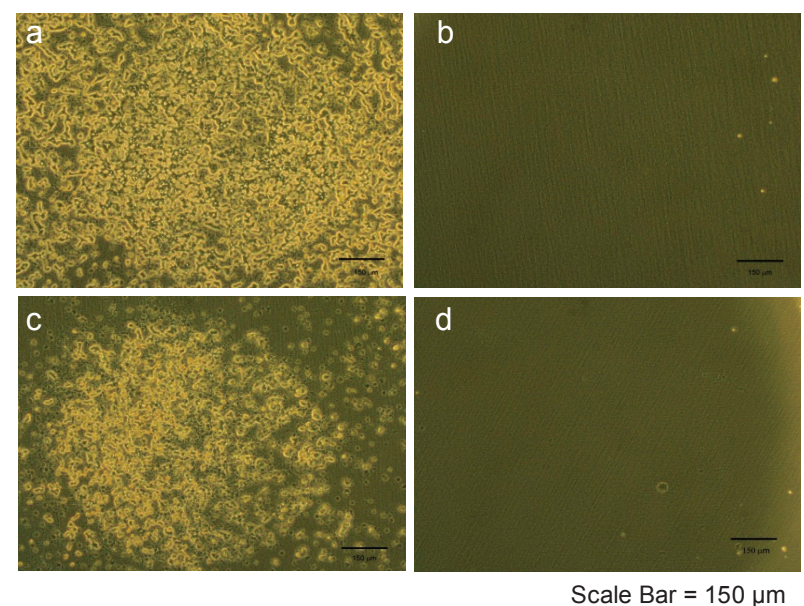

Figure 5. Inhibitory effect of 6 on the binding between sVCAM-1 and VLA-4 of THP-1 cells. (a) BCECF-AM-labeled THP-1 cells and 6 were added to 96-well plates coated with sVCAM-1. After incubation for $1 \mathrm{hr}$ at $37^{\circ} \mathrm{C}$, cells were dissolved in $1 \%$ Triton X-100 in PBS, and fluorescent intensity measured as described in Material and Methods. Monoclonal antibody (CD49d) was used as a positive control. The data are presented as the means of three independent experiments performed in duplicate. (b) The attachment of THP-1 cells was observed by microscopy (Nikon eclipse TS100). Total magnification was $\times 100$. a: cells added to wells coated with sVCAM-1; b: cells added to wells not coated with sVCAM-1; c: cells and 6 ( 30.0 $\mu \mathrm{M})$ added to wells coated with sVCAM-1; d: cells and $6(60.0 \mu \mathrm{M})$ added to wells coated with sVCAM-1.

inhibited the direct binding between SVCAM-1 and VLA-4 of THP-1 cells in a dose-dependent manner, with $\mathrm{IC}_{50}$ values of 7.8 and $1.7 \mu \mathrm{M}$ (Figure 3), respectively. However, 3-5 did not show inhibitory activity with the cell adhesion assay $(<20 \%$ at $100.0 \mu \mathrm{M}$, data not shown). The activity was verified using monoclonal antibody $(\mathrm{CD} 49 \mathrm{~d})^{26}$ as a positive control, which inhibited cell adhesion with an $\mathrm{IC}_{50}$ value of $20.0 \mu \mathrm{M}$ in the present assay system. Simultaneously, $\mathbf{1}$ and $\mathbf{2}$ were confirmed as lacking any cytotoxic effects on the THP-1 cells at the concentrations employed in this study (data not shown).

As shown in Figure 2 and 3, 4 and 5, possessing methoxy and methylhydroxy groups, and two sugar moieties, did not show inhibitory activity on the direct binding between the SVCAM-1 and VLA-4 of THP-1 cells. However, 1 and 2, having an epoxy group and two sugar moieties, showed potent inhibitory activities compared with $\mathbf{4}$ and $\mathbf{5}$ in this assay. This result suggests that the presence of the epoxy group could affect the cell adhesion inhibitory activity. Nevertheless, $\mathbf{3}$, having an epoxy group and three sugar moieties, did not show inhibitory activity and suggests that the increase in sugar moieties could decrease the cell adhesion inhibitory activity of these compounds. In addition, 2 has a hydroxyl group ( $\alpha$ form) at the C-16 position, compared with 1 ( $\beta$ form). The inhibitory activity of $\mathbf{2}$ showed a higher potency with an $\mathrm{IC}_{50}$ value of $1.7 \mu \mathrm{M}$, compared to 1 , indicating that the hydroxyl group ( $\alpha$ form) slightly improves the potency on cell adhesion activity. As a result, cell adhesion inhibitory activities of these compounds may be positively influenced by the presence of the epoxy moiety and hydroxyl group ( $\alpha$-form) at the C-16 position.

Whether the aglycone (6), lacking the two sugar moieties of 2, shows inhibitory activity in the binding between SVCAM-1 and VLA-4 of THP-1 cells was also addressed. On the preferential basis, 2 was treated with an alcoholic alkali metal solution for the preservation of the epoxy moiety in the aglycone (6, Scheme 1), ${ }^{22}$ and the reactant subjected to semi-preparative

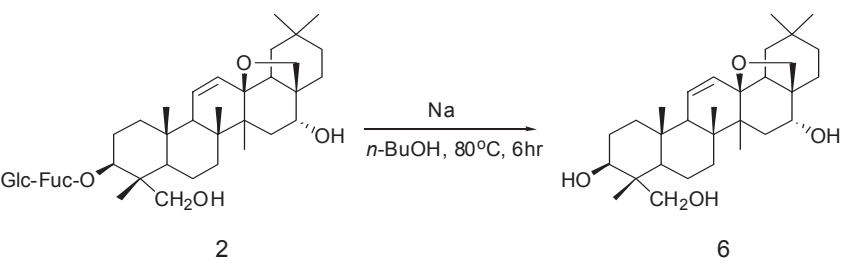

Scheme 1

HPLC to yield 6. An LC-MS technique was applied to analyze 6, described in Materials and Methods. As shown in Figure 4, 6 showed a fragment ion peak at $m / z=471.8$ formed when the molecular ion lost the sugar moieties of 2 . In the ${ }^{1} \mathrm{H}-\mathrm{NMR}$ spectrum of 6, two olefinic proton signals at $\delta 6.08(1 \mathrm{H}, \mathrm{d}, J=10.0$ $\mathrm{Hz}, \mathrm{H}-12)$ and $5.73(1 \mathrm{H}, \mathrm{dd}, J=3.0,10.3 \mathrm{~Hz}, \mathrm{H}-11)$, and six methyl protons at $\delta 1.63,1.40,1.09,1.09,1.04$, and 0.98 (each $3 \mathrm{H}, \mathrm{s}, \mathrm{H}-24,25,26,27,29,30-\mathrm{Me}$ ) were detected. Above all, the NMR spectra of $\mathbf{6}$ did not reveal the anomeric proton and carbon signals observed at $\delta 5.36,4.99,107.2$, and 106.4 in the NMR spectra of 2 . Based on the above evidence, its structure was confirmed through NMR and MS spectra analysis, and compared with the literature, ${ }^{23-25}$ as saikogenin G (6). Compound 6 inhibited the binding between SVCAM-1 and VLA-4 of THP-1 cells in a dose-dependent manner, with $\mathrm{IC}_{50}$ values of $21.1 \mu \mathrm{M}$ (Figure 5). Although the cell adhesion inhibitory activity of aglycone (6) had 12-fold less potency by removing the two sugar moieties of $\mathbf{2}$, it still showed moderate inhibitory activity in the cell adhesion assay. Therefore, $\mathbf{6}$ could be an attractive pharmacophore for the design of anti-inflammatory agents.

In conclusion, five saikosaponins (1-5) were isolated from the roots of Bupleurum falcatum L. by active-guide fractionation. Among them, compound $\mathbf{2}$ showed the highest potency with an $\mathrm{IC}_{50}$ value of $1.7 \mu \mathrm{M}$ in the assay system, with the aglycone structure of $\mathbf{2}$ also showing cell adhesion inhibitory activity. 
Recent reports have indicated that anti-inflammatory activities of saikosaponins by reduction of cyclooxygenase (COX) and lipoxygenase (LOX) production and inhibition of T cell activation upon modulation of NF-kB activation. ${ }^{28-29}$ Also, it reduced production of pro-inflammatory cytokines such as IL-6, TNF- $\alpha$, and INF- $\gamma$ during T cell activation. ${ }^{30}$ Moreover, new findings that these compounds possess inhibitory effects on the VLA-4/VCAM-1 interaction have been presented in this paper. Therefore, these results could be useful for the design of new cell adhesion inhibitors to lead to anti-inflammatory agents.

Acknowledgments. This research was supported by the National Research Foundation of Korea (NRF) (No. 2009-0081750) grant funded by the Korea government (MEST) and a KRIBB Research Initiative Program.

\section{References}

1. McEver, R. P. Curr. Opin. Cell Biol. 1992, 272, 60.

2. Springer, T. A. Cell 1994, 76, 301.

3. Butcher, E. C. Cell 1991, 67, 1033 .

4. Rose, D. M.; Alon, R.; Ginsberg, M. H. Immunol. Rev. 2007, 218 , 126.

5. Elices, M. J.; Osborn, L.; Takada, Y.; Crouse, C.; Luhowskyj, S.; Hemler, M. E.; Lobb, R. R. Cell 1990, 60, 577.

6. Postigo, A. A.; Teixido, J.; Sanchez-Madrid, F. Res. Immunol. 1993, 144, 723 .

7. Tilley, J. W. Expert. Opin. Ther. Patents 2002, 12, 991.

8. Lin, K.; Ateenq, H. S.; Hsiunig, S. H.; Chong, L. T.; Zimmerman, C. N.; Castro, A.; Lee, W. C.; Hammond, C. E.; Kalkunte, S.; Chen, L. L.; Pepinsky, R. B.; Leone, D. R.; Sprague, A. G.; Abraham, W. M.; Gill, A.; Lobb, R. R.; Adams, S. P. J. Med. Chem. 1999, 42, 920.

9. Previtali, S. C.; Hartung, H. P. Trends Neuosci. 1999, 22, 30.

10. Carter, R. A.; Wicks, I. P. Arthritis. Rheum. 2001, 44, 985.

11. Kato, S.; Hokari, R.; Matsuzaki, K.; Iwai, A.; Kawaguchi, A.; Nagao, S.; Miyahara, T.; Itoh, K.; Ishii, H.; Miura, S. J. Pharmacol.
Exp. Ther. 2000, 295, 183.

12. Tubridy, N.; Behan, P. O.; Capildeo, R.; Chaudhuri, A.; Forbes, R.; Hawkins, C. P.; Hughes, R. A.; Palace, J.; Sharrack, B.; Swingler, R. J.; Young, C.; Moseley, I. F.; MacManus, D. G.; Donoghue, S.; Miller, D. H. Neurology 1999, 53, 466.

13. Gordon, F. H.; Lai, C. W. Y.; Hamilton, M. I.; Allison, M. C.; Srivastava, E. D.; Fouweather, M. G.; Donoghue, S.; Greenlees, C.; Subhani, J.; Amlot, P. L.; Pounder, R. E. Gastroenterology 2001, $121,268$.

14. Huang, K. Antipyretic Herbs. In the Pharmacology of Chinese Herbs; CRC Press: Tokyo, 1993; p 151.

15. Takai, K.; Shibata, M. Yakugaku Zasshi 1969, 89, 1367.

16. Zhou, Z.; Wang, G.; Ma, J. J. Tradit. Chin. Med. 1983, 3, 103.

17. Shibata, M.; Yoshida, R.; Motohashi, S. Yakugaku Zasshi 1973, 93 , 1660.

18. Ishii, H.; Nakamura, M.; Seo, S.; Tori, K.; Tozyo, T.; Yoshimura, Y. Chem. Pharm. Bull. 1980, 28, 2367.

19. Tori, K.; Seo, S.; Yoshimura, Y.; Nakamura, M.; Yutaka, T.; Ishii, H. Tetrahedron Lett. 1976, 46, 4167.

20. Kunoata, T.; Hinoh, H. Tetrahedron Lett. 1967, 9, 303.

21. Shimaoka, A.; Seo, S.; Minato, H. J. Chem. Soc. Perkin Trans. 1975, 2043.

22. Nose, M.; Amagaya, S.; Takeda, T.; Ogihara, Y. Chem. Pharm. Bull. 1989, 37, 1293.

23. Kubota, T.; Hinoh, H. Tetrahedron 1967, 24, 675.

24. Aimi, N.; Fujimoto, H.; Shibata, S. Chem. Pharm. Bull. 1968, 16, 641.

25. Tori, K.; Yoshimura, Y.; Seo, S.; Sakurawi, K.; Tomita, Y.; Ishii, H. Tetrahedron Lett. 1976, 46, 4163.

26. Okigami, H.; Takeshita, K.; Tajimi, M.; Komura, H.; Albers, M.; Lehmann, T. E.; Rolle, T.; Bacon, K. B. Euro. J. Pharmacol. 2007, 559, 202.

27. Mosmann, T. J. Immunol. Methods 1983, 65, 55.

28. Bermejo, B. P.; Abad, M. M. J.; Silvan, S. A. M.; Sanz, G. A.; Fernandez, M. L.; Sanchez, C. S.; Diaz, L. M. Life Sci. 1998, 63, 1147.

29. Leng, C. Y.; Liu, L.; Wong, R. N.; Zeng, Y. Y.; Li, M.; Zhou, H. Biochem. Biophys. Res. Commun. 2005, 338, 1920.

30. Wong, V. K. W.; Zhou, H.; Cheung, S. S. F.; Li, T.; Liu, L. J. Biol. Chem. 2009, 107, 303. 